\title{
Mechanical and Thermal Properties of RCB Masonry Containing Three Rows of Holes
}

\author{
Hanquan Yuan $\mathbb{D}^{1},{ }^{1}$ Lihua Zhu $\mathbb{D}^{1,2}$ Yixuan Wang, ${ }^{1}$ and Fengjian Zhang ${ }^{3}$ \\ ${ }^{1}$ School of Civil Engineering, Xi'an University of Architecture \& Technology, 13 Yanta Road, Xi'an 710055, China \\ ${ }^{2}$ State Key Laboratory of Green Building in Western China, Xi'an University of Architecture \& Technology, 13 Yanta Road, \\ Xi'an 710055, China \\ ${ }^{3}$ School of Civil Engineering, Henan University of Urban Construction, Pingdingshan 467036, China \\ Correspondence should be addressed to Lihua Zhu; zhulihuaxa@163.com
}

Received 1 March 2021; Revised 29 June 2021; Accepted 8 July 2021; Published 16 July 2021

Academic Editor: Francesco Colangelo

Copyright (c) 2021 Hanquan Yuan et al. This is an open access article distributed under the Creative Commons Attribution License, which permits unrestricted use, distribution, and reproduction in any medium, provided the original work is properly cited.

\begin{abstract}
In order to promote and apply the structures of the recycled concrete block (RCB) masonry, the thermal and mechanical properties of the recycled concrete specimens were tested in this study. The RCB can meet load-bearing and seismic requirements and was prepared through experiments. Concurrently, the mechanical property experiment was conducted on the RCB masonry, and then its failure process and mode were discussed. In addition, a thermal property test was completed on the RCB wall, and the difference in the thermal properties of single-row hole, three-row hole, and solid blocks was analyzed by theoretical calculations. The results indicated that the mechanical properties of the RCB masonry were basically the same as those of the natural concrete block masonry, and they have good compressive stability. The calculation formulas of the compressive and shear strengths of the natural concrete block masonry are applicable to the RCB masonry. The RCB masonry containing three rows of holes owns more outstanding thermal property than natural concrete block masonry and satisfies the requirements for related codes.
\end{abstract}

\section{Introduction}

In recent years, the rapid urbanization development has resulted in a sharp increase in producing the construction and demolition wastes domestically [1]. Concurrently, China is a country with frequent earthquakes, which has resulted in numerous building wastes in a short time [2]. If construction waste is not dealt with appropriately, it leads to not only significant land occupation but also environmental pollution [3].

Construction waste disposal is a problem that has been of extensive concern globally, and it affects the sustainable development of the resources as well as the environment. The United States of America and the developed European countries have been studying this problem relatively early. According to a national survey conducted by the US Federal Highway Administration in 2004, 41 of the 50 states use recycled aggregates produced from construction waste [4]. According to the statistics from the Netherlands, the recycling rate of construction waste reached $90 \%$ in 2000 . The demolished concrete in the UK is approximately 28 million tons per year, of which 14.8 million tons are recycled, and the recycling rate is approximately $52 \%$ [5]. Recycled concrete aggregate is a kind of aggregate produced by the construction waste, which overcomes the difficulties introduced by construction waste, thus realizing the recycling of construction waste resources. This measure protects natural resources and the human living environment and has good social and environmental benefits.

Over the past decade, researchers from various countries have conducted numerous studies on recycled concrete [6-10]. Poon et al. [11] showed the characteristics of the concrete prepared by the recycled aggregates. Then they reported that, as the recycled aggregate content increased, the concrete's strength decreased, which correspondingly reduced the resistance to the concrete's chloride ion penetration. Xiao et al. [12] investigated the relationship among the compressive strength, density, and splitting tensile 
strength, as well as flexural strength of the recycled concrete, and it was determined that there might be a significant difference in the mechanical properties between the recycled and normal concretes. Currently, most researches have proved that recycled aggregates tend to degrade the mechanical properties of recycled concrete [13] owing to their characteristics of low apparent density, high water absorption, and large crushing index [14]. However, by reasonably designing or adjusting the mixing ratio, the recycled concrete's performance could be made to satisfy the specific requirements. Thus, the recycled concrete can be used in the construction industry to some extent [15]. Rodriguez et al. [16] applied recycled concrete to nonstructural concrete elements and tested their mechanical properties, carbonization resistance, and chloride ingress through experiments. The results show that the use of recycled aggregate can reduce the performance of concrete. Still, the addition of fly ash and slag can significantly improve most of the performance of recycled concrete elements, including long-term property. It can be found that recycled concrete is mainly used for roadbed and nonload-bearing structural member materials [17-20]. To expand the application scope of recycled concrete, it should be used in load-bearing structural components, such as structural walls. It is well known that, except for realizing a specific mechanical strength, a structural wall should own outstanding thermal insulation property [21].

In this paper, the mechanical property of RCB was studied. The RCB that meets the load-bearing requirement was prepared by experiment and used in load-bearing structural walls. The compressive and shear strength of the RCB containing three rows of holes and masonry was tested and theoretically analyzed, and the effect factors and failure modes of the strength of RCB were discussed. Considering that the RCB wall should not only meet the load-bearing requirements but also have good thermal insulation performance, the thermal resistance of the RCB wall was tested and calculated theoretically. These studies will promote the application of RCB masonry in practical engineering.

\section{Materials}

2.1. Cement. In order to investigate the effect of cement strength on the strength of RCB, PC32.5 and PC42.5 composite Portland cement that were produced by China Shaanxi Qinling Cement Plant were employed in this study. The physical and mechanical properties of cement are shown in Table 1.

2.2. Aggregates. The recycled concrete was originated from the construction waste, which was removed from an abandoned factory locally, and subsequently, it was squashed, swashed, and then screened to prepare recycled concrete aggregates in a waste recycling plant. The recycled concrete aggregates were classified as recycled fine and coarse aggregates, whose particle size is $0-5 \mathrm{~mm}$ as well as $5-10 \mathrm{~mm}$, respectively. Figure 1 shows the components of the recycled concrete aggregates. In Figure 1, the aggregates with a wrapping mortar percentage of less than $10 \%$ were undisturbed stones, and those with $10 \%-100 \%$ are secondary aggregates. The mortar lump comprised a pure mortar block as well as small stones, which were completely wrapped with the mortar, and other components including tiles, glass, and wood crumbs.

The natural aggregates included pebbles as well as river sands. The particle sizes of the pebbles ranged from $5 \mathrm{~mm}$ to $10 \mathrm{~mm}$, and the fineness modulus of the natural sand was 2.18 .

The primary materials' physical properties were tested, as shown in Table 2. It was found that, compared with the apparent and bulk densities of the natural aggregates, those of the recycled concrete aggregates were significantly lower. Therefore, it could be concluded that the recycled concrete aggregates' water absorption was significantly greater than that of the natural aggregates, and that of the recycled fine aggregates was 3.1 times larger than that of the recycled coarse aggregates.

\section{RCB Containing Three Rows of Holes}

3.1. Specimens and Mixture Proportions. A type of RCB with a porosity of $36 \%$ was developed, whose length is $390 \mathrm{~mm}$, width is $240 \mathrm{~mm}$, and height is $190 \mathrm{~mm}$, as shown in Figure 2. To best utilize the recycled concrete aggregates, the recycled coarse aggregate's replacement ratio was $100 \%$. Based on previous research [22], in this test, the unit water consumption as well as the water-cement ratio was set as $150 \mathrm{~kg} / \mathrm{m}^{3}$ and 0.4 , respectively. The sand rate, the replacement rate of recycled fine aggregate, and the strength grading of cement were changed. Among them, the recycled fine aggregates replacement ratio was $0 \%, 40 \%$, and $100 \%$, respectively. The sand rate was $45 \%, 50 \%$, and $55 \%$, and the strength grading of cement was PC 32.5 and PC42.5, respectively. The details of the concrete mixtures as well as their mixture proportions are summarized in Table 3. There were six groups in the test and five blocks in each group.

3.2. Experimental Procedures. A material machine (TYE2000E) was used to test an RCB, as shown in Figure 3. The compressive strength test was carried out in accordance with "Test methods for the concrete block and brick" (GB/T 41112013) [23], and the load was applied using a force-controlled load actuator at a rate of $10 \mathrm{kN} / \mathrm{s}$.

In the early loading stage, as the load increased, the reading from the material testing machine steadily increased, and the surface of the RCB did not change. When the load was approximately $70 \%$ of the ultimate load of the $\mathrm{RCB}$, some fine cracks appeared on its surface, and the reading from the material testing machine increased slowly. As the load further increased, the number of cracks on the surface of the RCB increased. However, when there was an ultimate load, the deformation of the RCB increased rapidly, the reading of the material testing machine decreased, and the RCB was destroyed. Figure 4 shows the specimens' failure process. 
TABle 1: Physical and mechanical properties of cement.

\begin{tabular}{|c|c|c|c|c|c|c|c|c|c|}
\hline \multirow{4}{*}{ Cement } & \multirow{4}{*}{ Assessment } & \multicolumn{8}{|c|}{ Property } \\
\hline & & \multirow{2}{*}{\multicolumn{2}{|c|}{ Setting time $(\min )$}} & \multirow{2}{*}{\multicolumn{2}{|c|}{$\begin{array}{c}\text { Chemical } \\
\text { composition (\%) }\end{array}$}} & \multicolumn{4}{|c|}{ Strength $(\mathrm{MPa})$} \\
\hline & & & & & & \multicolumn{2}{|c|}{$\begin{array}{l}\text { Compressive } \\
\text { strength }\end{array}$} & \multicolumn{2}{|c|}{$\begin{array}{l}\text { Flexural } \\
\text { strength }\end{array}$} \\
\hline & & Initial set & Final set & $\mathrm{SO}_{3}$ & $\mathrm{MgO}$ & $3 \mathrm{~d}$ & $28 \mathrm{~d}$ & $3 \mathrm{~d}$ & $28 \mathrm{~d}$ \\
\hline \multirow{2}{*}{ PC32.5 } & Allowable value & $\geq 45$ & $\leq 600$ & $\leq 3.5$ & $\leq 6.0$ & $\geq 10.0$ & $\geq 32.5$ & $\geq 2.5$ & $\geq 5.5$ \\
\hline & Test value & 240 & 330 & 2.1 & 2.0 & 18.9 & 38.4 & 4.2 & 6.8 \\
\hline \multirow{2}{*}{ PC42.5 } & Allowable value & $\geq 45$ & $\leq 600$ & $\leq 3.5$ & $\leq 6.0$ & $\geq 15.0$ & $\geq 42.5$ & $\geq 3.5$ & $\geq 6.5$ \\
\hline & Test value & 210 & 270 & 2.3 & 2.1 & 27.4 & 52.9 & 6.1 & 7.1 \\
\hline
\end{tabular}

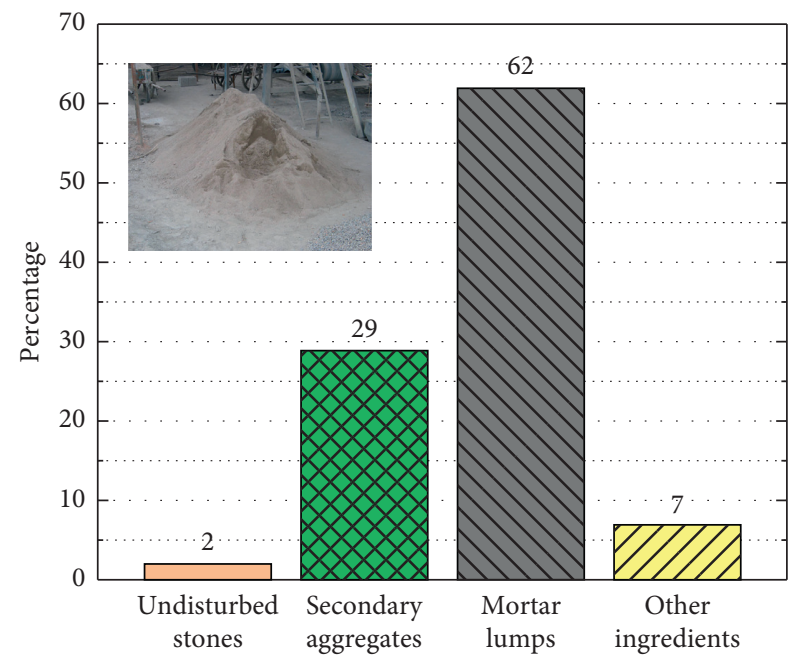

(a)

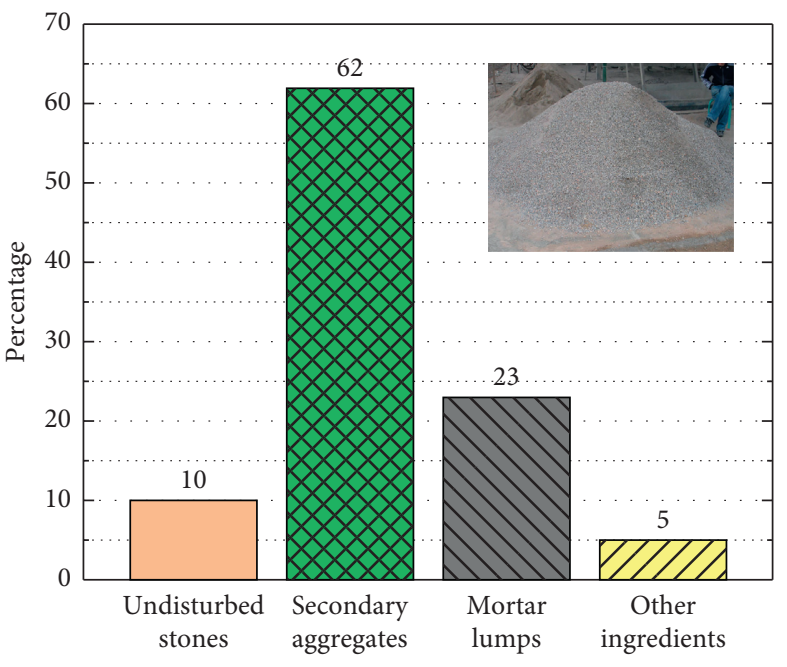

(b)

Figure 1: Composition of recycled concrete aggregates. (a) Recycled fine aggregates (0-5 mm); (b) recycled coarse aggregates (5-10 mm).

TABLe 2: Physical properties of aggregates.

\begin{tabular}{lcccccc}
\hline Type & Size $(\mathrm{mm})$ & $\begin{array}{c}\text { Apparent density } \\
\left(\mathrm{kg} / \mathrm{m}^{3}\right)\end{array}$ & $\begin{array}{c}\text { Bulk density } \\
\left(\mathrm{kg} / \mathrm{m}^{3}\right)\end{array}$ & $\begin{array}{c}\text { Water absorption } \\
(\%)\end{array}$ & Crush index & Fineness modulus \\
\hline Recycled fine aggregates & $0-5$ & 2489.6 & 1141.5 & 10.91 & 21.70 & 2.78 \\
Natural fine aggregates & $0-5$ & 2724.8 & 1448.4 & 1.02 & - & 2.18 \\
Recycled coarse aggregates & $5-10$ & 2521.7 & 1096.1 & 3.50 & 24.74 & - \\
Natural coarse aggregates & $5-10$ & 2801.8 & 1407.0 & 0.47 & 5.99 & - \\
\hline
\end{tabular}

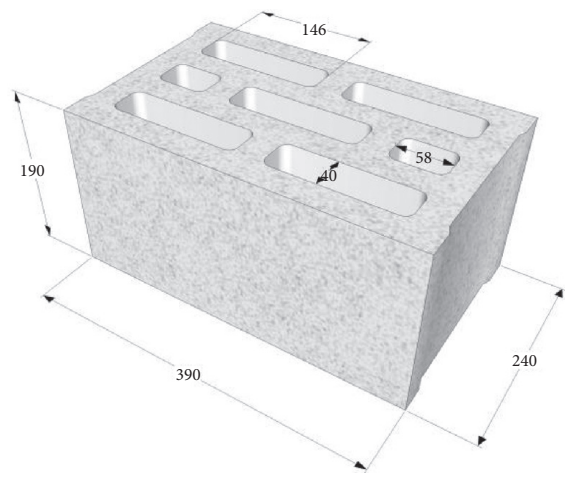

(a)

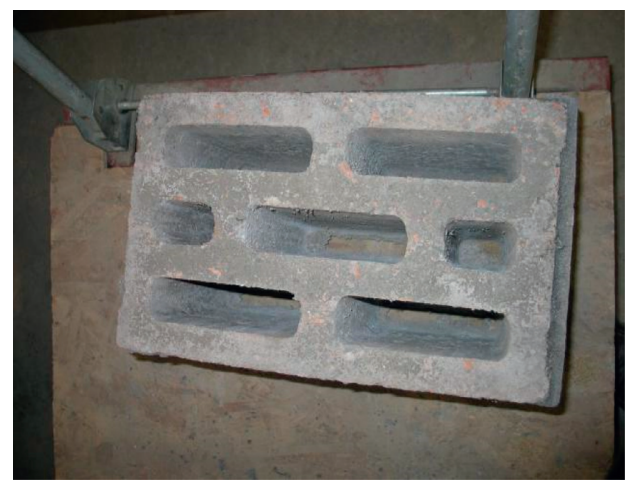

(b)

Figure 2: RCB containing three rows of holes. (a) Dimensions (mm); (b) actual diagram. 
TABLE 3: Mixture proportions of RCB $\left(\mathrm{kg} / \mathrm{m}^{3}\right)$.

\begin{tabular}{|c|c|c|c|c|c|c|c|c|}
\hline Group & Replacement ratio of RFA (\%) & Sand ratio $(\%)$ & Strength grading of cement & Water & Cement & RCA & RFA & NFA \\
\hline $\mathrm{R} 1$ & 100 & 45 & PC32.5 & 150 & 375 & 866 & 709 & 0 \\
\hline $\mathrm{R} 2$ & 40 & 50 & PC32.5 & 150 & 375 & 788 & 315 & 472 \\
\hline R3 & 0 & 55 & PC32.5 & 150 & 375 & 709 & 0 & 866 \\
\hline $\mathrm{R} 4$ & 100 & 45 & PC42.5 & 150 & 375 & 866 & 709 & 0 \\
\hline R5 & 40 & 50 & PC42.5 & 150 & 375 & 788 & 315 & 472 \\
\hline R6 & 0 & 55 & PC42.5 & 150 & 375 & 709 & 0 & 866 \\
\hline
\end{tabular}

RFA: recycled fine aggregates, RCA: recycled coarse aggregates, NFA: natural fine aggregates, and sand ratio: (RFA + NFA)/(RCA + RFA + NFA).

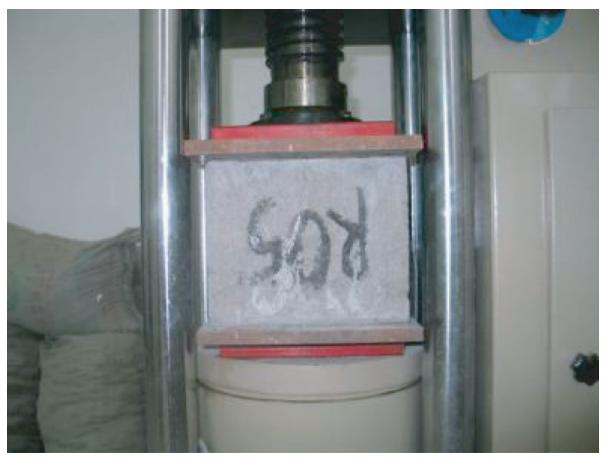

Figure 3: Compression test.

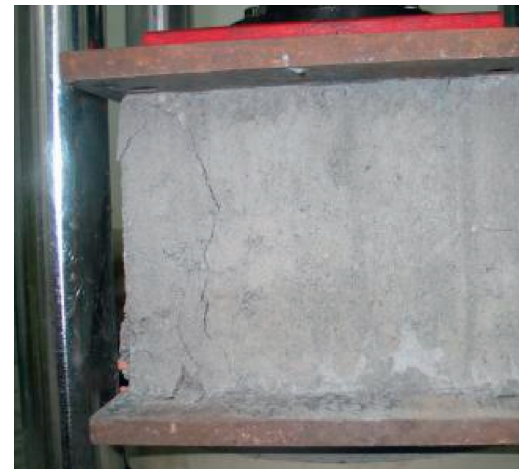

(a)

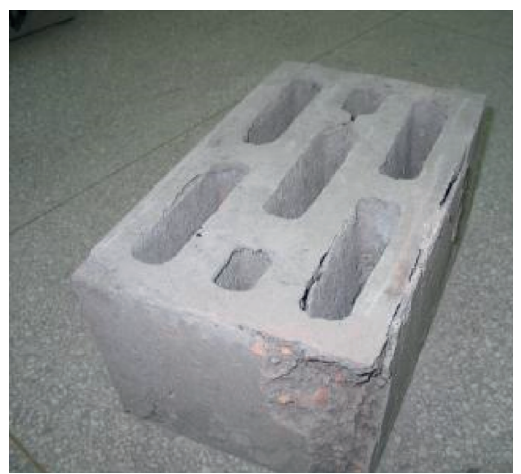

(b)

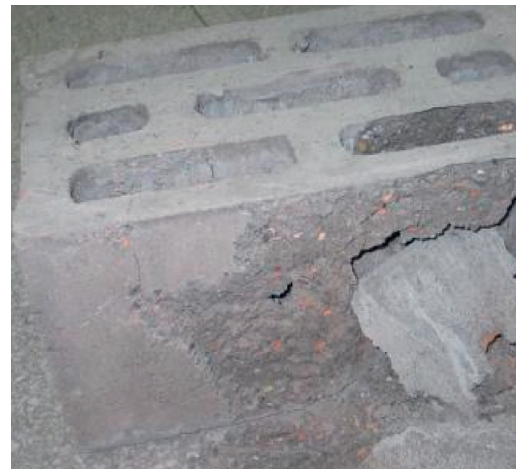

(c)

Figure 4: Failure process of specimens. (a) Cracks on surface; (b) failure on edge; (c) final failure.

3.3. Experimental Results and Discussion. During the test process, the maximum load, $P$, of each RCB was recorded. Later, the compressive strength was calculated. Then the average compressive strength of five blocks was determined for each mixture proportion. Table 4 shows the test results.

Figures 5 and 6 show the effects of the sand and replacement ratios between the recycled fine aggregates and the compressive strength of the RCB, respectively. It was inferred that, for the recycled fine aggregates' same sand or replacement ratio, the compressive strength of the blocks with cement PC 42.5 was higher than that of the RCB with cement PC 32.5. It was also found that, with the increase of the sand ratio as well as the decrease of the recycled fine aggregates' replacement rate, the compressive strength of the RCB increased.

The effects of the recycled fine aggregates' replacement ratio on the recycled concrete blocks' compressive strength were mainly focused on in this study. The brick strength grade in the masonry structure was represented by MU, and MU5 means that the average compressive strength of the block is not less than $5 \mathrm{MPa}$ [23].

For groups R1 and R4, the recycled aggregates were adopted to replace the entire coarse and fine aggregates, and it could be observed that the compressive strength of the RCB, which were prepared by using PC32.5 and PC42.5 cement, both reached the strength level of MU5.0, which satisfied the minimum requirements of the loadbearing block in the Chinese standard (the strength grade of load-bearing blocks is not less than MU5.0) [24]. The allowable compressive stress of hollow load-bearing block is $4.83 \mathrm{MPa}$ in "Building Code Requirements and Specification for Masonry Structures" (ACI 530/530.113) of the United States [25], which is similar to the Chinese Code. 
TABLE 4: Mixture proportions of RCB.

\begin{tabular}{lccc}
\hline Group & Average compressive strength $(\mathrm{MPa})$ & Least compressive strength $(\mathrm{MPa})$ & $v(\%)$ \\
\hline R1 & 5.8 & 4.7 & 15.95 \\
R2 & 7.1 & 6.0 & 13.91 \\
R3 & 8.8 & 8.5 & 3.67 \\
R4 & 6.5 & 5.5 & 17.42 \\
R5 & 7.8 & 6.3 & 11.37 \\
R6 & 11.0 & 10.2 & 5.82 \\
\hline
\end{tabular}

$v$ : variation coefficient.

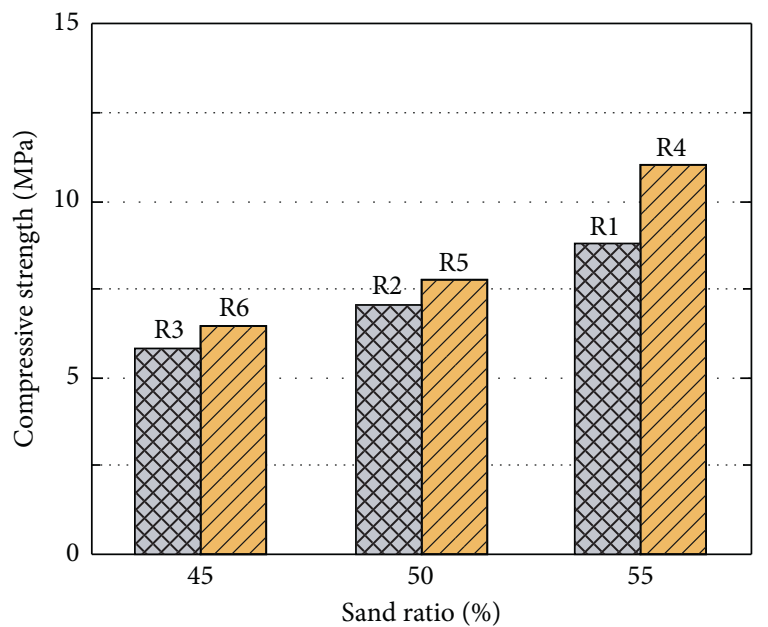

PC 32.5 Dत PC42.5

Figure 5: Effect of sand rate on compressive strength.

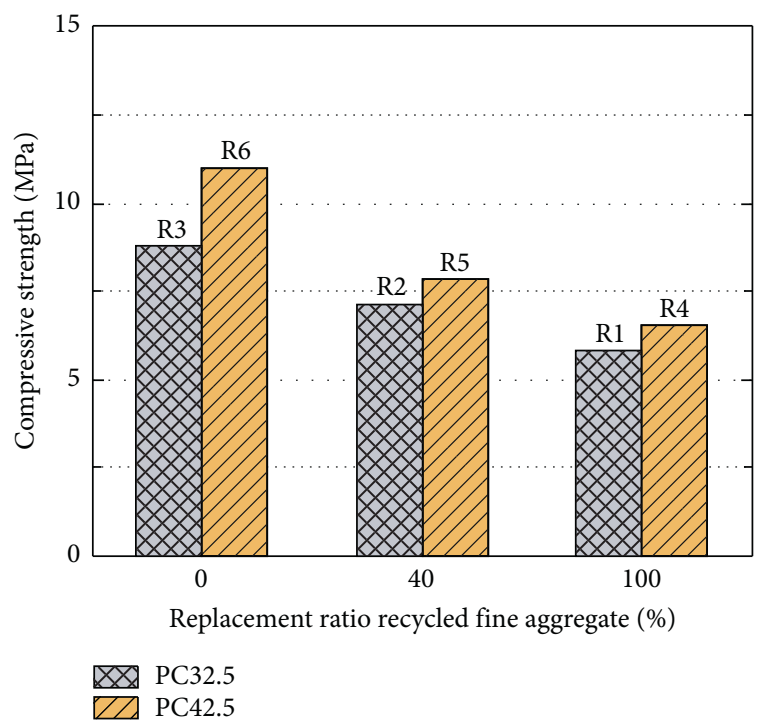

FIGURE 6: Effect of replacement ratio for recycled fine aggregate on compressive strength.

For groups R2 and R5, the recycled fine aggregate's replacement ratio was $40 \%$. Then the blocks' compressive strength grew to the strength level of MU7.5, which satisfied the seismic requirements (the strength grade of the block used for the seismic structure is not less than MU7.5) [26].
However, the ACI code does not make requirements for the strength of hollow blocks in terms of seismic design.

For groups R3 and R6, the coarse aggregates were the recycled coarse aggregates, and the fine aggregates were only the natural fine aggregates. The strength grades of the blocks prepared by PC32.5 and PC42.5 cement reach those of MU7.5 and MU10.0, respectively.

Figure 7 shows the strength variation coefficient of the RCB. It was found that, as the recycled fine aggregates' replacement ratio increased, the variation coefficient also increased. When their replacement ratio reached 0 , the variation coefficient was $4 \%-6 \%$, and when the former was $100 \%$, the variation coefficient increased to $14 \%-18 \%$. This indicated that the recycled fine aggregates would increase the difficulty of the quality control of the RCB.

\section{RCB Masonry}

4.1. Specimens and Mixture Proportions. As indicated by the experimental results of the recycled concrete blocks, the mixture proportions of groups R5 and R6 were chosen to produce two types of recycled concrete blocks of strength grades MU7.5 and MU10.0. The mortar strength had the following grades, including M5, M7.5, M10, and M15 (according to Chinese Code "standard for test method of basic properties of construction mortar" (JGJ/T70-2009), M5 means that the average compressive strength of cube mortar blocks of side $70.7 \mathrm{~mm}$ is not less than $5 \mathrm{MPa}$ ). Table 5 shows the six groups of recycled concrete block masonries that were produced. There were three pieces of masonry in each group. The size of each RCB masonry is shown in Figure 8, and the mortar's thickness is $10 \mathrm{~mm}$.

4.2. Experimental Procedures. A YE-200A machine was used to test the RCB masonries' compressive and shear strengths, which are shown in Figures 9 and 10, respectively.

The specimens underwent three stages during the compression test. The first stage was from the start of the loading to the appearance of the initial crack. During this stage, with the increase in the load, the readings of the mechanical dial indicator for measuring the horizontal and longitudinal deformations of the masonry increased smoothly. When the first fine crack appeared on the surface of the specimen, the initial load was recorded. The second stage was from the initial crack load to the ultimate load. During this stage, there were fine vertical cracks first appearing on the lateral surface along the masonry's width direction, and subsequently with the increase in the load, 


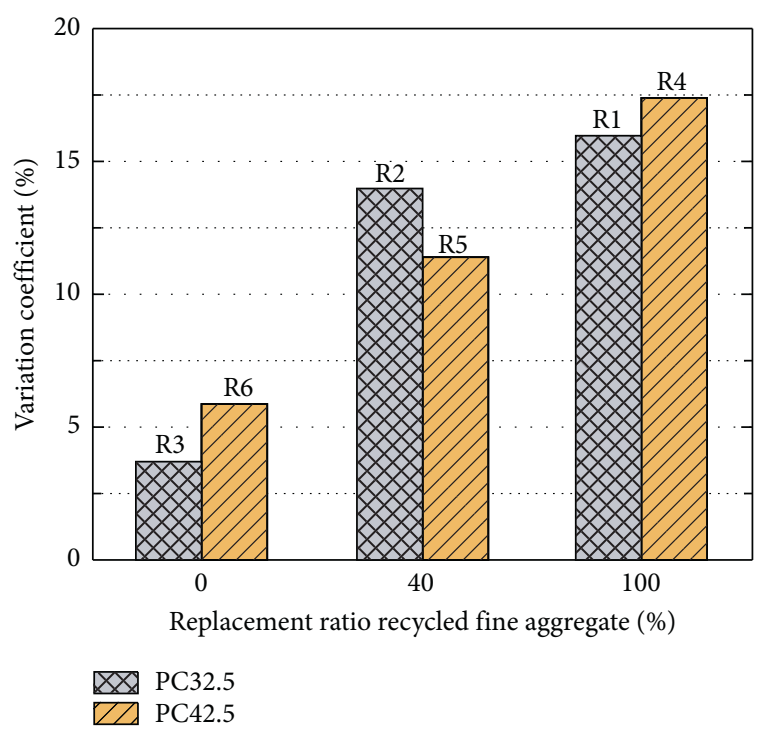

FIGURE 7: Effect of replacement ratio for recycled fine aggregate on variation coefficient.

TABLE 5: Combination of RCB masonry.

\begin{tabular}{lcc}
\hline Group & Block $(\mathrm{MPa})$ & Mortar $(\mathrm{MPa})$ \\
\hline A1 & 10.5 & 8.0 \\
A2 & 10.5 & 12.0 \\
A3 & 10.5 & 14.8 \\
B1 & 7.53 & 6.2 \\
B2 & 7.53 & 8.0 \\
B3 & 7.53 & 12.0 \\
\hline
\end{tabular}

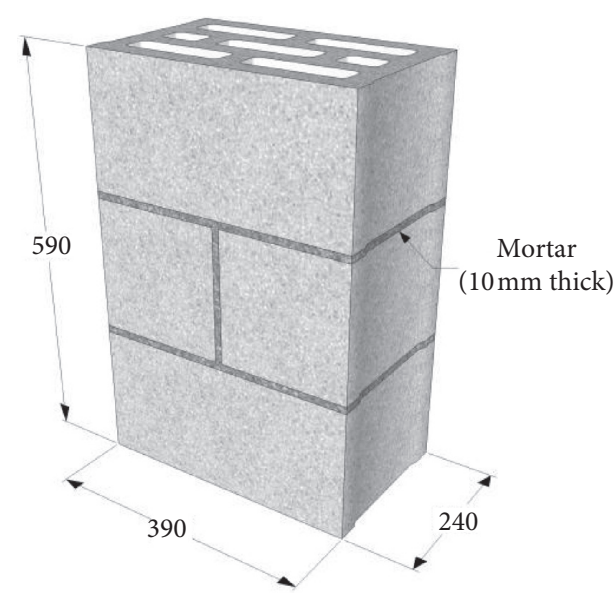

Figure 8: RCB masonry containing three rows of holes.

vertical or oblique ones appeared on the lateral surface along the length direction. Then the cracks gradually propagated and penetrated. The readings from the mechanical dial indicator showed a rapid increase. The third stage was from the ultimate load to the failure of the masonry. Penetrating cracks were formed, and the specimen broke into several small block columns. Finally, the specimen was crushed and failed.

The shear strength tests were carried out on the RCB masonries under constant-speed continuous loading, and the loading time was approximately 1-3 min. Each specimen presented no abnormal phenomena from the beginning of the loading to the failure, which is a typical brittle failure. The shear failure of the masonries occurred at the mortar surface, and the RCB remained intact. It can be considered that the mortar strength played a major role in the RCB masonries' shear strength and that the single shear failure of the masonries was more than double the shear failure. As indicated by the Standard for "Test Method of Basic Mechanical Properties of Masonry" (GB/T50129-2011) [27], it can be known that the RCB masonries' compressive and shear strengths were calculated, as shown in Table 6.

4.3. Experimental Results and Discussion. As indicated by the Standard for "Test Method of Basic Mechanical Properties of Masonry" (GB/T50129-2011) [27], it can be known that the RCB masonries' compressive and shear strengths were calculated, as shown in Table 6.

Figure 11 shows the effect of the ultimate load on the cracking load of the RCB masonry. A significantly linear relationship between the ultimate load and cracking load was observed, with the ratio fluctuating around 0.69 , and the cracking load increases with the increase in the ultimate load. This trend is basically the same as that for the natural aggregate concrete, indicating that the recycled concrete's compressive performance has good stability and can be widely used in practical engineering.

As it was difficult to measure the descent section of the RCB masonries' stress-strain curves on the YE-200A machine, so only the ascending sections were discussed. Because the slope of each stress-strain curve represents the elastic modulus; therefore, the larger the masonry's elastic modulus was, the higher its compressive strength would be. It can be seen from Figure 12 that regardless of group A or group $\mathrm{B}$ with the increase of the mortar strength, the masonries' compressive strength would also increase. However, their deformation decreases. Figure 13 shows the effect of $\mathrm{RCB}$ strength and mortar strength on the RCB masonry strength.

Figure 13 shows that the strength of the RCB masonry was positively correlated with mortar strength and RCB strength. For the compressive strength of RCB masonry, the strength of the block increased by $39 \%$, and the strength of masonry can be increased by $48 \%$. The strength of mortar increased by $50 \%$, and the strength of the block only increases by $8.3 \%$, which indicates that the RCB strength is the main factor affecting the compressive strength of the RCB. However, the effect of mortar strength on the shear strength of RCB masonry was reversed. The strength of the block increased by $39 \%$, and the strength of RCB masonry can be increased by $9.1 \%$. The strength of mortar strength only increased by $23 \%$, and the strength of the RCB increases by $10.7 \%$, which shows that the mortar strength is the main factor affecting the RCB masonry shear strength. The results may be because connection between the RCB is done by mortar.

The change rate in the RCB masonry strength can be described by the slope of the fitted line. It can be observed 


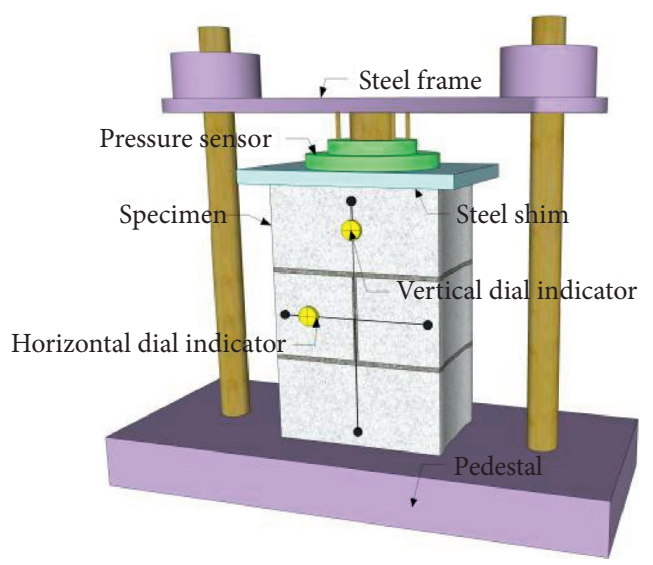

(a)

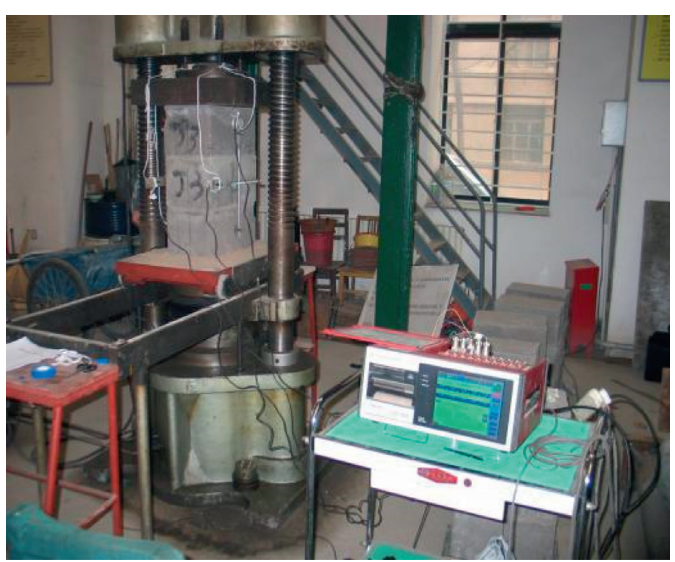

(b)

FIGURE 9: Specimens employed for testing compressive strength. (a) Schematic diagram; (b) actual diagram.

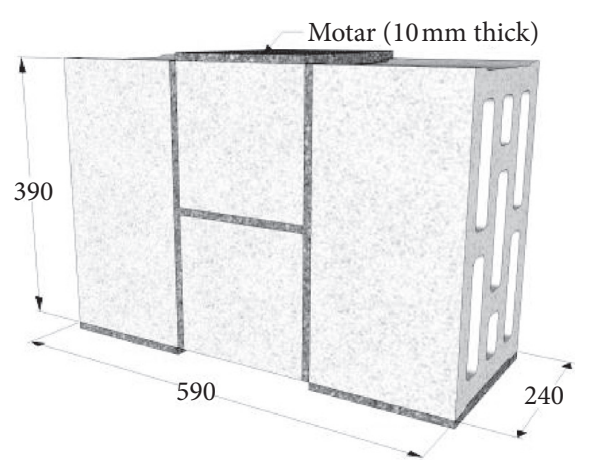

(a)

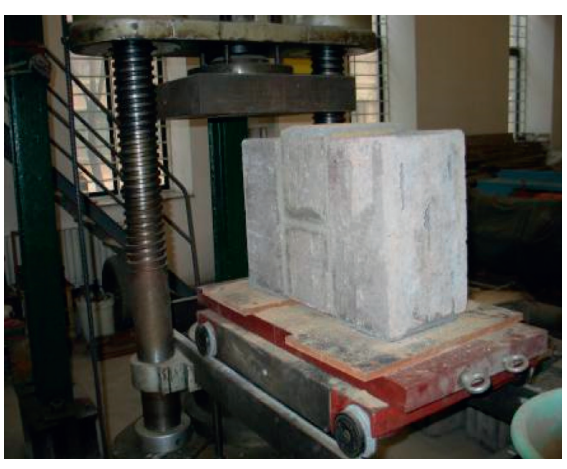

(b)

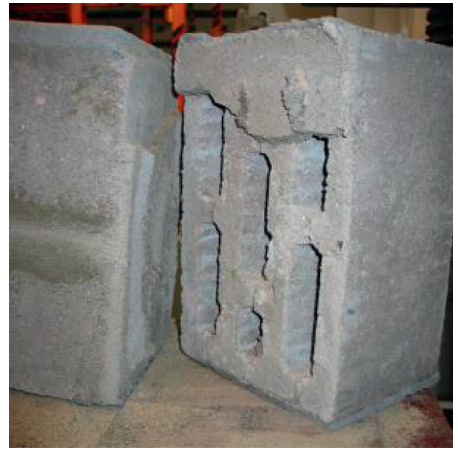

(c)

Figure 10: Specimens employed for testing shear strength. (a) Dimensions (mm); (b) shear test; (c) shear failure.

TABLE 6: Compressive and shear strength of RCB masonry.

\begin{tabular}{|c|c|c|c|c|c|c|c|c|c|c|}
\hline \multirow{2}{*}{ Group } & \multirow{2}{*}{ Block (MPa) } & \multirow{2}{*}{ Mortar (MPa) } & \multicolumn{5}{|c|}{ Compressive strength test } & \multicolumn{3}{|c|}{ Shear strength test } \\
\hline & & & $P_{\mathrm{c}}(\mathrm{kN})$ & $P_{\mathrm{u}}(\mathrm{kN})$ & $P_{\mathrm{c}} / P_{\mathrm{u}}$ & $f_{1}(\mathrm{MPa})$ & $\mathrm{v}(\%)$ & $P_{\mathrm{u}}(\mathrm{kN})$ & $f_{2}(\mathrm{MPa})$ & $v(\%)$ \\
\hline A1 & 10.50 & 8.0 & 480.3 & 712.3 & 0.67 & 7.61 & 0.15 & 22.46 & 0.24 & 0.14 \\
\hline A2 & 10.50 & 12.0 & 513.2 & 771.3 & 0.66 & 8.24 & 0.03 & 26.21 & 0.28 & 0.16 \\
\hline A3 & 10.50 & 14.8 & 623.1 & 802.3 & 0.78 & 8.57 & 0.11 & 29.02 & 0.31 & 0.18 \\
\hline B1 & 7.53 & 6.2 & 299.7 & 422.1 & 0.71 & 4.51 & 0.24 & 17.78 & 0.19 & 0.23 \\
\hline B2 & 7.53 & 8.0 & 373.8 & 479.2 & 0.78 & 5.12 & 0.17 & 20.59 & 0.22 & 0.20 \\
\hline B3 & 7.53 & 12.0 & 401.1 & 581.2 & 0.69 & 6.21 & 0.21 & 25.27 & 0.27 & 0.25 \\
\hline
\end{tabular}

$P_{\mathrm{c}}$ : cracking load, $P_{\mathrm{u}}$ : ultimate load, $f_{1}$ : compressive strength of masonry, $f_{2}$ : shear strength of masonry, and $v$ : variation coefficient.

that the mortar strength has a significant effect on the RCB masonry strength when the RCB strength is low. This result may be related to the unstable of RCB at low strength, which indirectly increases the effect of mortar, thus making it become the main factor affecting the strength of RCB masonry.

4.4. Calculation of RCB Masonry Strength. Based on the "Code for Design of Masonry Structures" (GB50003-2011) [24], the compressive and shear strengths are expressed as follows:

$$
\begin{aligned}
f_{m} & =k_{1} f_{1}^{\alpha}\left(1+0.07 f_{2}\right) k_{2}, \\
f_{v, m} & =k_{5} \sqrt{f_{2}},
\end{aligned}
$$

where $f_{m}$ represents the calculated masonry compressive strength, $f_{v, m}$ represents the calculated masonry shear strength, $f_{1}$ denotes the blocks' average compressive strength, and $f_{2}$ represents the mortars' average compressive strength, while $\alpha$ and $k_{1}$ are the influence values of the block appearance, dimension, and masonry modus of masonry blocks with different types, and $k_{2}$ is the mortar's influence 


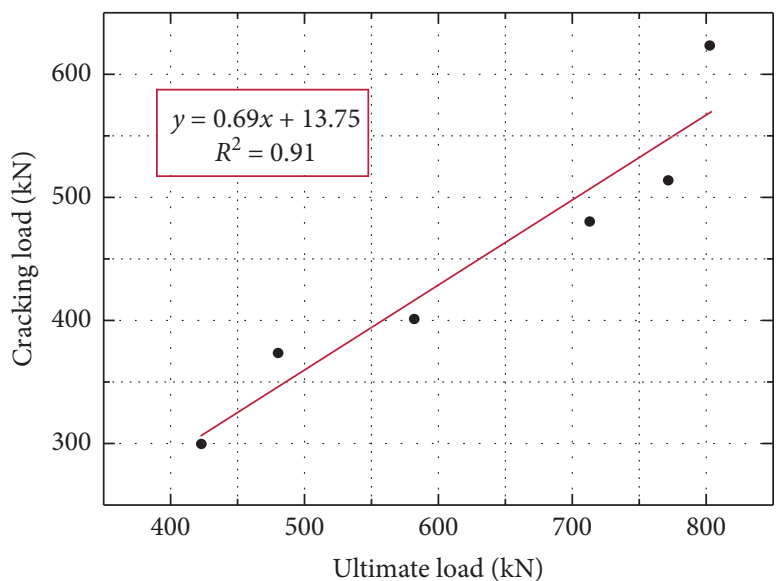

FIGURE 11: Relations between cracking load and ultimate load of six groups of RCB masonry.
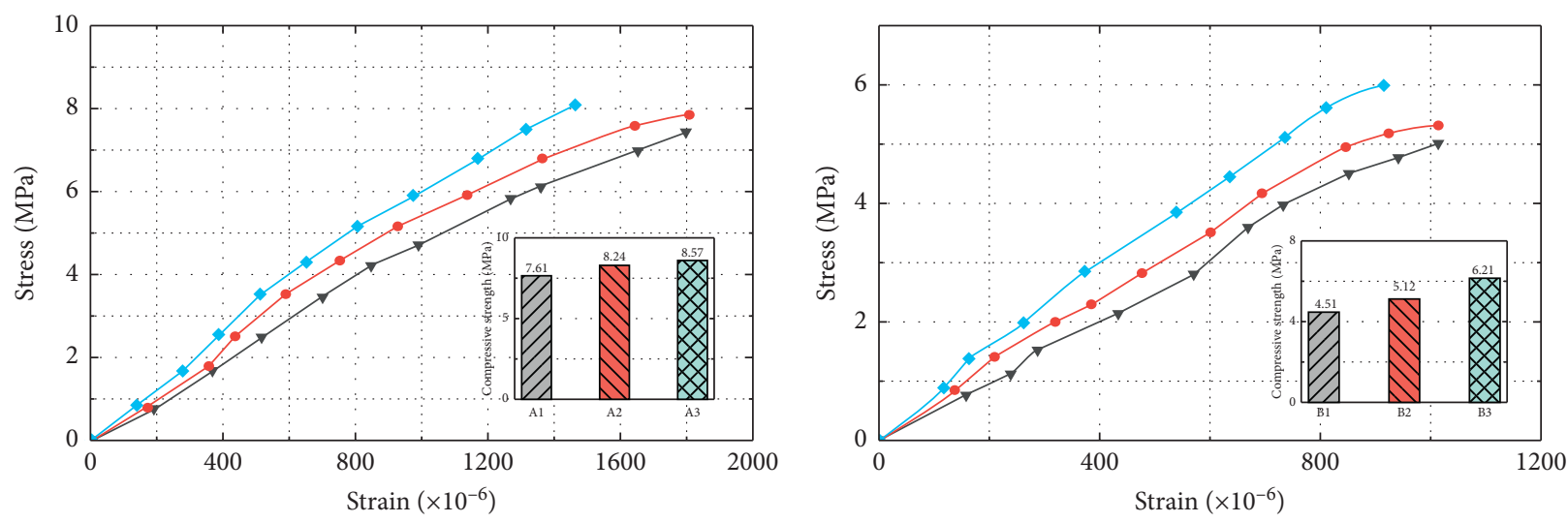

$$
\begin{aligned}
& \rightarrow \mathrm{A} 1 \\
& \rightarrow \mathrm{A} 2 \\
& \rightarrow \mathrm{A} 3
\end{aligned}
$$$$
\begin{aligned}
& \rightarrow \mathrm{B} 1 \\
& \multimap \mathrm{B} 2 \\
& \multimap \mathrm{B} 3
\end{aligned}
$$

(a)

Figure 12: Stress-strain curves. (a) Group A; (b) group B.

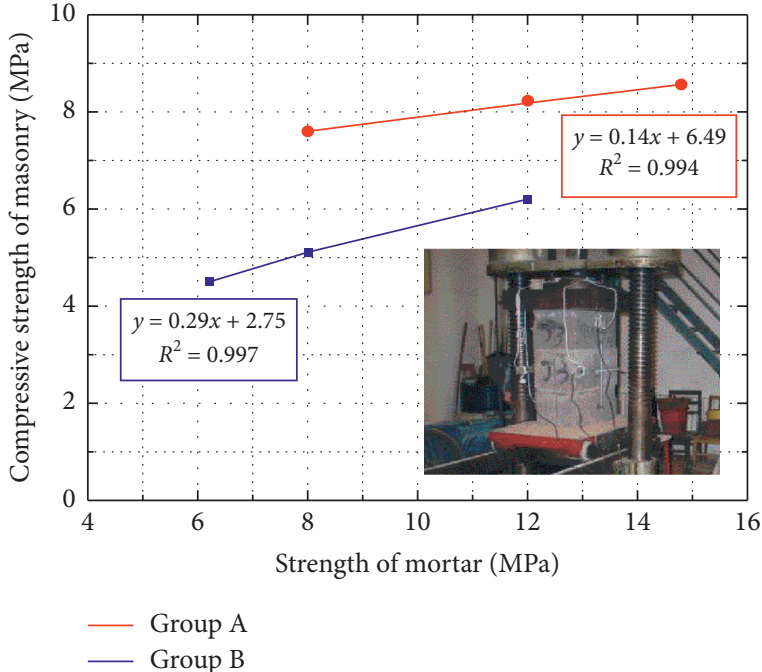

(a)

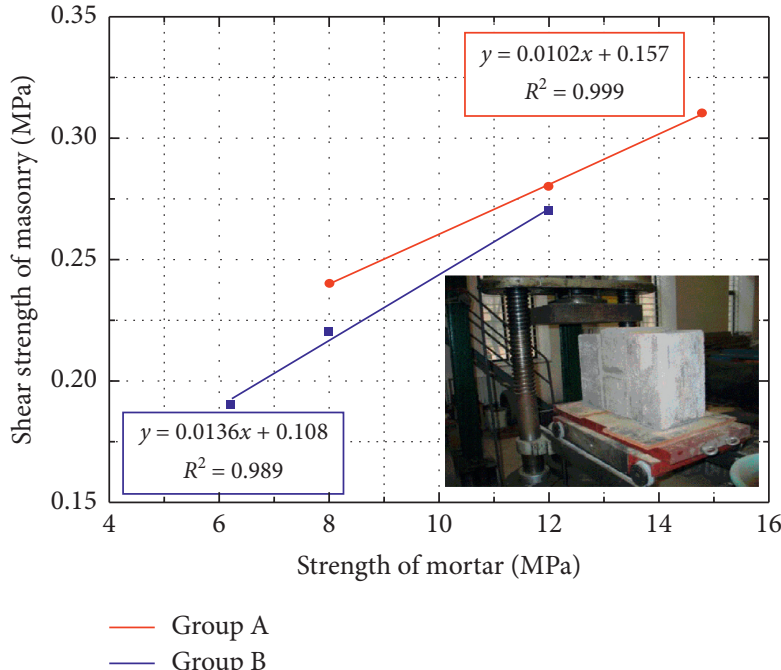

(b)

FIGURE 13: Effect of RCB strength and mortar strength on the RCB masonry strength. (a) Compressive strength; (b) shear strength. 
coefficient on the masonry's compressive strength. Besides, $k_{5}$ represents the coefficient related to the masonry type. For concrete blocks, $\alpha=0.9, k_{1}=0.46$, and $k_{5}=0.069$. When $f_{2} \neq 0, k_{2}=1.0$.

Considering the discreteness of the RCB strength, it increased the reliability of the parameter values in the code. The results that were calculated by using equations (1) and (2) are shown in Table 7.

As shown in the test results, it could be seen that the RCB masonries' compressive and shear strengths were higher than the results calculated by the equation. The ratio of the test and calculated results was concentrated between 1.1 and 1.2 , which indicates that the natural aggregate concrete block masonries' compressive and shear strength formulas can be adapted to obtain the RCB masonries' mechanical strength.

The design of a masonry structure requires to satisfy the material strength's standard as well as the design values. A normal distribution should be adopted in the material strength's probability distribution, and the probability distribution of 0.05 quantile can determine its standard value. As the masonry strength follows a normal distribution [28], $f_{k}$, the compressive strength's standard value, can be expressed by the following formula:

$$
f_{k}=f_{m}-1.645 \sigma_{f}=f_{m}\left(1-1.645 \delta_{f}\right),
$$

where $f_{m}$ is the calculated masonry compressive strength, $\sigma_{f}$ is the compressive strength's standard deviation, and $\delta_{f}$ is the strength variation coefficient. As shown in Table 5, the average variation coefficients of the masonries in groups A and $\mathrm{B}$ are 0.1 and 0.21 , respectively. Considering structural safety, the coefficient variation of masonry's compressive strength is 0.21 .

$f$, the strength used in the design of masonry structural components in accordance with the final bearing state, is called the masonries' strength design value. When the influence of the factors is considered, such as the variation in the geometric parameters and uncertainty of the calculation mode on the reliability, $f$ can be expressed by the following formula:

$$
f=\frac{f_{k}}{\gamma_{f}},
$$

where $\gamma_{f}$ is the partial coefficient of the material property of the masonry structure. In general, it should be considered based on the construction quality level as B, and $\gamma_{f}=1.6$ [24].

The RCB required high water absorption and had porous recycled aggregates; therefore, their construction quality was difficult to control. If a reliable strength design wants to be guaranteed, $\gamma_{f}$ can be increased to 1.7. The standard and design values for the calculation formulas of the shear strength of the RCB masonry were the same as equations (3) and (4), and the variation coefficient of the shear strength was chosen as 0.19 . Table 8 summarizes the standard as well as the design values of the recycled concrete block masonries' compressive and shear strengths.

\section{RCB Wall}

5.1. Specimens. In general, the walls were built by using the $\mathrm{RCB}$, and the insulation performance of the walls is of extreme importance for engineering applications. By adding a heat preservation material to masonry to form a composite wall for energy conservation and heat preservation, we can satisfy the relevant indexes of the "Design Standard for Energy Efficiency of Public Buildings” (GB50189-2015) [29], thus realizing a broad application prospect. In this study, two walls were built using the designed blocks mentioned in Section 4.1: one (W1) with an extruded PS foam insulation board (EPS) and the other (W2) without EPS. The sizes of the specimens are shown in Figure 14.

5.2. Experimental Procedures. The test instrument was a JWI heat transfer coefficient tester of the RCB walls and a JW-II building thermal temperature and heat flow automatic test system containing hot and cold boxes, a specimen shelf, and temperature sensors. The tests of two specimens were conducted with reference to a Chinese standard (GB/T 10295-2008) [30], which is shown in Figure 15. Each specimen was placed for a month until the RCB wall was dry. The hot and cold boxes were attached to the specimen frame. The instrument was started, and the test was conducted continuously for eight hours.

5.3. Experimental Results and Discussion. The test yielded that the surface temperature of the hot chamber wall and the cold chamber wall was $26.4^{\circ} \mathrm{C}$ and $-1.8^{\circ} \mathrm{C}$, respectively. $\mathrm{W} 1$ had a heat transfer coefficient of $1.41 \mathrm{~W} /\left(\mathrm{m}^{2} \cdot \mathrm{K}\right)$ as well as a thermal resistance of $0.559 \mathrm{~m}^{2} \cdot \mathrm{K} / \mathrm{W}$. Meanwhile, W2 had a heat transfer coefficient of $1.62 \mathrm{~W} /\left(\mathrm{m}^{2} \cdot \mathrm{K}\right)$ and thermal resistance of $0.467 \mathrm{~m}^{2} \cdot \mathrm{K} / \mathrm{W}$.

It can be found that the thermal resistance of the concrete block containing three rows of holes is higher than that of the concrete block with a single-row hole after a comparison based on the "Technical Specification for Concrete Small-sized Hollow Block Masonry Buildings" (JGJ/T142011) [31], as summarized in Table 9. The thermal insulation of the RCB is $52.3 \%$ higher than that of the natural concrete block containing three rows of holes. The thermal resistance increases by $0.092 \mathrm{~m}^{2} \cdot \mathrm{K} / \mathrm{W}$ after adding EPS to the recycled concrete block, making it $20 \%$ higher than that previously reported, and the thermal insulation become more significant.

The calculation formula in the "Thermal Design Code for Civil Building" (GB50176-2016) [32] cannot be directly used because the recycled concrete and holes in the hollow block are not merely superimposed. Thus, the thermal resistance of the hollow blocks was calculated by the formula when there is a combination wall [23]. Then a composite wall's average thermal resistance can be calculated by the following formula: 
TABLE 7: Test and calculated results of the RCB masonries' compressive and shear strengths.

\begin{tabular}{|c|c|c|c|c|c|c|c|c|}
\hline \multirow{2}{*}{ Group } & \multirow{2}{*}{ Block (MPa) } & \multirow{2}{*}{ Mortar (MPa) } & \multicolumn{3}{|c|}{ Compressive strength test } & \multicolumn{3}{|c|}{ Shear strength test } \\
\hline & & & $f_{m}^{\prime}(\mathrm{MPa})$ & $f_{m}(\mathrm{MPa})$ & $f_{m}^{\prime} / f_{m}$ & $f_{v, m}^{\prime}(\mathrm{MPa})$ & $f_{v, m}(\mathrm{MPa})$ & $f_{v, m}^{\prime} / f_{v, m}$ \\
\hline$\overline{\mathrm{A} 1}$ & 10.5 & 8.0 & 7.61 & 5.96 & 1.28 & 0.24 & 0.20 & 1.23 \\
\hline $\mathrm{A} 2$ & 10.5 & 12.0 & 8.24 & 7.03 & 1.17 & 0.28 & 0.24 & 1.17 \\
\hline A3 & 10.5 & 14.8 & 8.57 & 7.78 & 1.10 & 0.31 & 0.27 & 1.17 \\
\hline B1 & 7.53 & 6.2 & 4.51 & 4.06 & 1.11 & 0.19 & 0.17 & 1.14 \\
\hline B2 & 7.53 & 8.0 & 5.12 & 4.42 & 1.16 & 0.22 & 0.20 & 1.08 \\
\hline B3 & 7.53 & 12.0 & 6.21 & 5.76 & 1.08 & 0.27 & 0.24 & 1.13 \\
\hline
\end{tabular}

$f_{m}^{\prime}$ and $f_{v m}^{\prime}$ : test results and $f_{m}$ and $f_{v m}$ : calculated results.

TABLE 8: Standard and design values of compressive and shear strengths of RCB masonries.

\begin{tabular}{|c|c|c|c|c|c|c|}
\hline \multirow{2}{*}{ Group } & \multirow{2}{*}{ Block (MPa) } & \multirow{2}{*}{ Mortar (MPa) } & \multicolumn{2}{|c|}{ Compressive strength $(\mathrm{MPa})$} & \multicolumn{2}{|c|}{ Shear strength $(\mathrm{MPa})$} \\
\hline & & & Standard values & Design values & Standard value & Design value \\
\hline A1 & 10.5 & 8.0 & 4.98 & 2.93 & 0.133 & 0.078 \\
\hline A2 & 10.5 & 12.0 & 5.39 & 3.17 & 0.163 & 0.096 \\
\hline A3 & 10.5 & 14.8 & 5.61 & 3.30 & 0.181 & 0.106 \\
\hline B1 & 7.53 & 6.2 & 2.95 & 1.73 & 0.117 & 0.069 \\
\hline B2 & 7.53 & 8.0 & 3.35 & 1.97 & 0.133 & 0.078 \\
\hline B3 & 7.53 & 12.0 & 4.06 & 2.39 & 0.163 & 0.096 \\
\hline
\end{tabular}

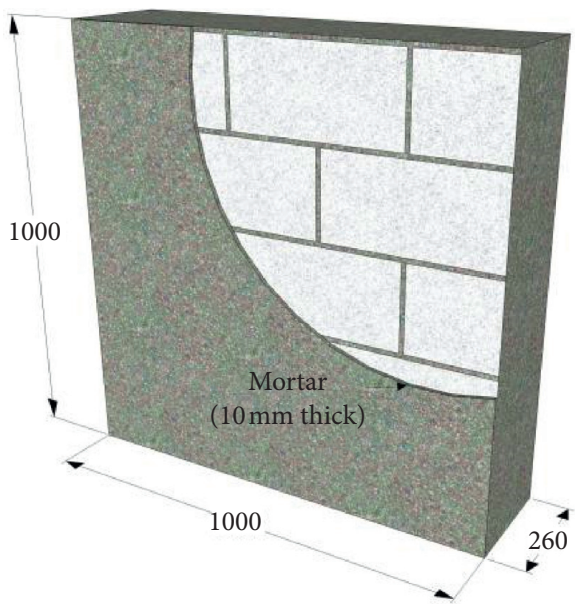

FIGURE 14: Size of RCB wall containing three rows of holes.

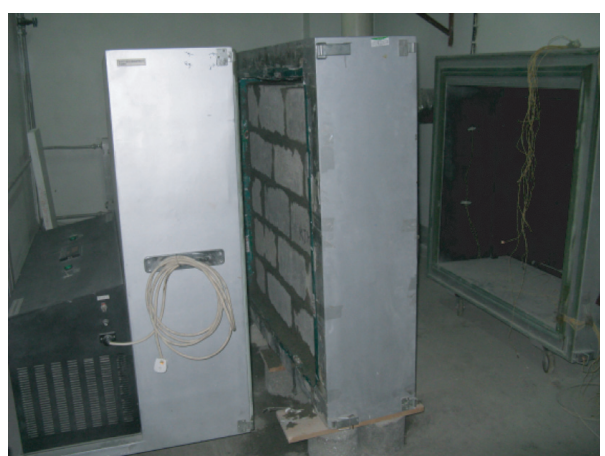

(a)

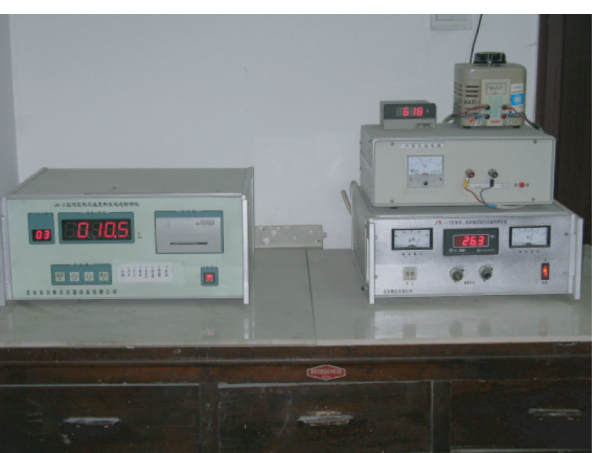

(b)

Figure 15: Test instrument. (a) JW-I; (b) JW-II. 
TABLE 9: Thermal parameters of block masonries.

\begin{tabular}{lccc}
\hline Composition & Size $(\mathrm{mm})$ & Type & Thermal resistance $\left(\mathrm{m}^{2} \cdot \mathrm{K} / \mathrm{W}\right)$ \\
\hline Natural aggregates & $390 \times 190 \times 190$ & Three-row hole & 0.3 \\
Recycled aggregates & $390 \times 240 \times 190$ & Three-row hole & 0.467 \\
Recycled aggregates & $390 \times 240 \times 190$ & Three-row hole (EPS) & 0.559 \\
\hline
\end{tabular}

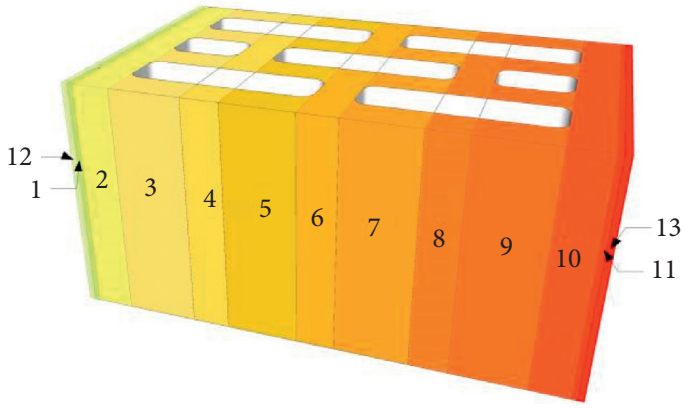

FIGURE 16: Heat transfer channel division of blocks.

$$
R=\left[\frac{F_{0}}{F_{1} / R_{0,1}+F_{2} / R_{0,2}+\cdots \cdots+F_{n} / R_{0, n}}-\left(R_{i}+R_{e}\right)\right] \varphi,
$$

where $R$ represents the average thermal resistance; $F_{0}$ represents the complete heat transfer area which is vertical to the heat flow direction. Meanwhile, $F_{1}, F_{2}, \ldots, F_{n}$ are the heat transfer areas that are parallel to the heat flow direction, while $R_{0,1}, R_{0,2}, \ldots, R_{0, n}$ are the heat transfer resistance at the heat transfer surface; $R_{i}$ represents the inner surface's heat transfer resistance, and it is taken as $0.11 \mathrm{~m}^{2} \cdot \mathrm{K} / \mathrm{W} ; R_{e}$ represents the outer surface's heat transfer resistance, and it is taken as $0.04 \mathrm{~m}^{2} \cdot \mathrm{K} / \mathrm{W}$. Finally, $\varphi$ denotes a correction coefficient.

It is shown in Figure 16 that the total heat transfer surface which is vertical to the heat flow direction is divided into 13 heat transfer surfaces, of which 12 and 13 are mortars of $5 \mathrm{~mm}$ on the block's left and right sides.

The thermal resistance of RCB containing three rows of holes was calculated by formula (5) as $0.63 \mathrm{~m}^{2} \cdot \mathrm{K} / \mathrm{W}$, which was slightly higher than the experimental results. The results due to the holes of the three-row hole block had chamfers, and the chamfers are not converted into square holes of the same area in the simplified calculation, which makes the air area of the holes extremely large.

In the same calculation method, the calculated thermal resistance of the RCB containing a single row of holes (porosity is $48 \%$ ) with the same thickness is $0.59 \mathrm{~m}^{2} \cdot \mathrm{K} / \mathrm{W}$. It can be found that, though the RCB containing three rows of holes (porosity is $36 \%$ ) have less porosity, they have a higher thermal resistance. This is because the staggered-array holes appeared in the blocks, which expands the heat conduction path. Meanwhile, it can be compared by calculation that the thermal resistance of recycled concrete solid brick is much smaller than that of hollow block, which is only $0.23 \mathrm{~m}^{2} \cdot \mathrm{K} /$ $\mathrm{W}$, indicating that hollow block has excellent thermal insulation performance. In addition, the three-row hole block can reduce material consumption while making its strength meet MU7.5, which is suitable for load-bearing walls.

\section{Conclusions}

This study aimed to survey the mechanical and thermal properties of an RCB masonry containing three rows of holes, and then the following conclusions were drawn:

(1) As the recycled fine aggregate's replacement rate increased, the RCB's compressive strength reduced. The strength grade of the prepared RCB masonry containing three rows of holes ranged from MU5.0 to MU10.0, which could meet the load-bearing and seismic requirements.

(2) Based on the compression test of the RCB masonry containing three rows of holes, the cracking load had a high correlation with the ultimate load, and their ratio remained basically unchanged. Therefore, there was an outstanding stable compressive property in the RCB masonry.

(3) The test results of the RCB masonry's compressive strength and shear strength were greater than the calculated results. The ratio of the test and calculated results lies within 1.1-1.2, which indicated that the mechanical strength of RCB masonry could be calculated by the compressive and shear strength formulas of the natural aggregate concrete block masonry. Therefore, the RCB masonry' strength standard and design values were calculated.

(4) The thermal resistance of the RCB wall containing three rows of holes was tested and determined as $0.467 \mathrm{~W} / \mathrm{m}^{2} \cdot \mathrm{K}$. At the same time, the RCB's thermal insulation was $52.3 \%$ higher than that of the natural concrete blocks, so the thermal insulation performance increased by $20 \%$ after adding EPS.

(5) Compared to the single-row RCB, there is less porosity but higher thermal resistance in the $\mathrm{RCB}$ masonry containing three rows of holes; therefore, it is a better thermal property while meeting the loadbearing and seismic requirements.

\section{Data Availability}

The data used to support the findings of this study are available from the corresponding author upon request.

\section{Disclosure}

Hanquan Yuan and Lihua Zhu are the co-first authors of this paper. 


\section{Conflicts of Interest}

The authors declare that they have no conflicts of interest.

\section{Authors' Contributions}

Hanquan Yuan and Lihua Zhu contributed to conceptualization; Lihua Zhu helped in methodology, resources, supervision, and funding acquisition; Hanquan Yuan and Yixuan Wang were involved in validation and formal analysis; Yixuan Wang and Fengjian Zhang contributed to investigation; Hanquan Yuan helped in data curation, original draft preparation, review and editing, and project administration. All authors have read and agreed to the published version of the manuscript.

\section{Acknowledgments}

This work was funded by the project of the Shaanxi Province Key Research and Development Program on Industry Innovation Chain (2018ZDCXL-SF-03-03-01).

\section{References}

[1] S. A. Zareei, F. Ameri, N. Bahrami, P. Shoaei, H. Musaeei, and F. Nurian, "Green high strength concrete containing recycled waste ceramic aggregates and waste carpet fibers: mechanical, durability, and microstructural properties," Journal of Building Engineering, vol. 26, Article ID 100914, 2019.

[2] J. Xiao, W. Li, Y. Fan, and X. Huang, "An overview of study on recycled aggregate concrete in China (1996-2011)," Construction and Building Materials, vol. 31, pp. 364-383, 2012.

[3] I. B. Topçu and N. F. Günçan, "Using waste concrete as aggregate," Cement and Concrete Research, vol. 25, no. 7, pp. 1385-1390, 1995.

[4] K. Antonios, N. Demetrios, and F. P. Michael, "Mechanical and durability properties of concretes containing recycled lime powder and recycled aggregates," Construction and Building Materials, vol. 53, pp. 253-259, 2014.

[5] M. Tsujino, T. Noguchi, M. Tamura, M. Kanematsu, and I. Maruyama, "Application of conventionally recycled coarse aggregate to concrete structure by surface modification treatment," Journal of Advanced Concrete Technology, vol. 5, no. 1, pp. 13-25, 2007.

[6] L. Viviana, O. José, M. Pedro, T. Ester, and M. Giacomo, "Influence of waste brick powder in the mechanical properties of recycled aggregate concrete," Sustainability, vol. 10, Article ID 1037, 2018.

[7] K. H. Younis and K. Pilakoutas, "Strength prediction model and methods for improving recycled aggregate concrete," Construction and Building Materials, vol. 49, pp. 688-701, 2013.

[8] V. W. Y. Tam, C. M. Tam, and Y. Wang, "Optimization on proportion for recycled aggregate in concrete using two-stage mixing approach," Construction and Building Materials, vol. 21, no. 10, pp. 1928-1939, 2007.

[9] F. Debieb, L. Courard, S. Kenai, and R. Degeimbre, "Mechanical and durability properties of concrete using contaminated recycled aggregates," Cement and Concrete Composites, vol. 32, no. 6, pp. 421-426, 2010.

[10] M. Chakradhara Rao, S. K. Bhattacharyya, and S. V. Barai, "Influence of field recycled coarse aggregate on properties of concrete," Materials and Structures, vol. 44, no. 1, pp. 205-220, 2011.

[11] S.-C. Kou, C.-S. Poon, and H.-W. Wan, "Properties of concrete prepared with low-grade recycled aggregates," Construction and Building Materials, vol. 36, pp. 881-889, 2012.

[12] J.-Z. Xiao, J.-B. Li, and C. Zhang, "On relationships between the mechanical properties of recycled aggregate concrete: an overview," Materials and Structures, vol. 39, no. 6, pp. 655-664, 2006.

[13] T. Hao and D. Li, "Study on the basic mechanical properties of recycled concrete hollow block masonry," Applied Mechanics and Materials, vol. 438-439, pp. 749-755, 2013.

[14] J. Z. Xiao, Recycle Concrete, China Architecture and Building Press, Beijing, China, 2008.

[15] C. S. Poon and C. S. Lam, "The effect of aggregate-to-cement ratio and types of aggregates on the properties of pre-cast concrete blocks," Cement and Concrete Composites, vol. 30, no. 4, pp. 283-289, 2008.

[16] C. Rodríguez, I. Sánchez, I. Miñano, and F. Benito, "On the possibility of using recycled mixed aggregates and GICC thermal plant wastes in non-structural concrete elements," Sustainability, vol. 11, Article ID 633, 2019.

[17] F. G. Esteban, F. C. Javier, L. O. Luis, and L. G. Luis, "Study of the technical feasibility of increasing the amount of recycled concrete waste used in ready-mix concrete production," Materials, vol. 10, pp. 817-832, 2017.

[18] C. Settari, F. Debieb, E. H. Kadri, and O. Boukendakdji, "Assessing the effects of recycled asphalt pavement materials on the performance of roller compacted concrete," Construction and Building Materials, vol. 101, pp. 617-621, 2015.

[19] M. Arshad and M. F. Ahmed, "Potential use of reclaimed asphalt pavement and recycled concrete aggregate in base/ subbase layers of flexible pavements," Construction and Building Materials, vol. 151, pp. 83-97, 2017.

[20] M. N. Soutsos, K. Tang, and S. G. Millard, "The use of recycled demolition aggregate in precast concrete products - phase III: concrete pavement flags," Construction and Building Materials, vol. 36, pp. 674-680, 2012.

[21] T. Pavlu, K. Fortova, J. Divis, and P. Hajek, “The utilization of recycled masonry aggregate and recycled EPS for concrete blocks for mortarless masonry," Materials, vol. 12, no. 12, pp. 1923-1940, 2019.

[22] G. L. Bai, Y. Y. Chai, X. Lia, and Y. Z. Chang, "Experimental research on shear properties of recycle concrete," in Proceedings of the 2nd International conference on waste engineering and management," ICWEM 2010 RILEM proceedings, vol. 73, pp. 605-613, Shanghai, China, October 2010.

[23] China Standard Press, Test Methods for the concrete Block and Brick (GB/T 4111-2013), China Standard Press, Beijing, China, 2014.

[24] China Architecture and Building Press, Code for Design of Masonry Structures (GB 50003-2011), China Architecture and Building Press, Beijing, China, 2012.

[25] Masonry Standards Joint Committee, Building Code Requirements and Specification for Masonry Structures (ACI 530/ 530.1-13), The Masonry Society, Longmont, CO, USA, 2013.

[26] China Architecture and Building Press, Code for Seismic Design of Buildings (GB 50011-2010), China Architecture and Building Press, Beijing, China, 2016.

[27] China Architecture and Building Press, Standard for Test Method of Basic Mechanical Properties of Masonry (GB/ T50129-2011), China Architecture and Building Press, Beijing, China, 2011. 
[28] S. F. Xu and Z. M. Xiong, Masonry Structure, Science Press, Beijing, China, 2004.

[29] China Architecture and Building Press, Design Standard for Energy Efficiency of Public Buildings (GB50189-2015), China Architecture and Building Press, Beijing, China, 2015.

[30] China Standard Press, Steady State Thermal Resistance and Insulation Materials Related Properties-Heat Flow Meter Method (GB/T 10295-2008), China Standard Press, Beijing, China, 2008.

[31] U. K. Harper Collins, Technical Specification for Concrete Small-Sized Hollow Block Masonry Buildings (JGJ/T14-2011), Construction Industry Standard JGJ/T2011, Beijing, China, 2011.

[32] China Architecture and Building Press, Thermal Design Code for Civil Building (GB50176-2016), China Architecture and Building Press, Beijing, China, 2014. 